\title{
Distribution of Alpinia (Zingiberaceae) and their use pattern in Vietnam
}

\section{Nguyen Phuong Hanh ${ }^{1 *}$, Nguyen Quoc Binh ${ }^{2}$ and Bhupendra Singh Adhikari ${ }^{3}$}

${ }^{1}$ Department of Plant Resources, Institute of Ecology and Biological Resources (IEBR), Vietnam Academy of Science and Technology (VAST), 18 Hoang Quoc Viet, Hanoi, Vietnam

${ }^{2}$ Department of Biology, Vietnam National Museum of Nature (VNMN), Vietnam Academy of Science and Technology (VAST), 18 Hoang Quoc Viet, Nghia Do, Cau Giay, Hanoi, Vietnam

${ }^{3}$ Department of Habitat Ecology, Wildlife Institute of India, Chandrabani, Dehradun, India

\begin{abstract}
Genus Alpinia under the family Zingiberaceae is one of the important medicinal plants in Vietnam, which has a greater role in day to day life of Vietnamese people. Many species viz. Alpinia galanga, Alpinia oxyphylla and Alpinia conchigera are traditionally used in folk remedies to treat diseases like cold, stomachache, bloating, digestive disorders and joint pain and are very effective. Until now, there are many species used to treat incurable diseases such as fatty liver, cirrhosis of liver and cancer. The present paper deals with the distribution and traditional knowledge of different species of Alpinia among Vietnamese.
\end{abstract}

Keywords: Alpinia; Ethno-botany; Medicinal plant; Traditional knowledge; Vietnam; Zingiberaceae

\section{Introduction}

The world population ca. $65-80 \%$ in developing countries depends on medicinal plants for primary health care, due to poverty and lack of access to modern medicine [1]. Vietnam is one of high biodiversity rich countries of the world with diverse flora. A total of 13766 plant species (2393 non-vascular and 11373 vascular plants) have been recorded in Vietnam, of which $3 \%$ of genera are endemic [2], and only ca. 3900 medicinal plant species has been used to treat various diseases [3]. The present paper deals with the distribution of Alpinia species and their traditional use by the local communities in Vietnam to cure various diseases. The people living in rural and mountainous areas are economically marginalized, but rich with natural resources in their vicinity. They don't have enough access to modern medicine and mainly depends on natural resources for medicine based on their traditional knowledge received through generations.

In recent years, there has been an increasing interest in the study on plants as a medicinal source and their traditional uses in different parts of Vietnam. There have been many reports of traditional medicinal plants for curing diseases by Vietnams' ethnic minorities and indigenous communities (54 different ethnic communities). Most of the ethnic communities have their own cultural traditions of using locally available animal and plant species, while many traditional remedies are closely guarded cultural secrets. Traditional medicine systems in Vietnam comprises of Traditional Vietnamese Medicine and Traditional Chinese Medicine, have a history spanning over 2000 years. The Government of Vietnam launched a programme "Strategy for Development of Traditional Medicine in Viet Nam to 2010" in 2002 and encouraging community preventive and curative health care through these systems, which has become now state policy to equally support the use of traditional and western medicine [3]. Today, an estimated $75 \%$ percent of Vietnamese people use traditional medicine as their primary source of treatment for common health problems [3].

\section{Material and Methods}

\section{Study area}

Vietnam is among one of the biodiversity rich countries in the world. Vietnam occupies the eastern and southern part of the IndoChinese peninsula in Southeast Asia, covering an area 3,31,123 $\mathrm{km}^{2}$ (north to south length of 1,650 km) along with south China sea coast, China in the north and Laos and Cambodia are in the west with 63 provinces. Vietnamese are basically the descendants of nomadic Mongols from China and migrants from Indonesia.

The country varies from mountainous (the Hoang Lien Son mountain range in the northwest up to $3000 \mathrm{~m}$ to coastal plains of the Red river delta and Mekong river delta) covers ca. $75 \%$ and only $15 \%$ of area is farm land [4]. The climate of Vietnam lies in the tropics and varies considerably from North to South and depends on the southwest monsoon in summer and rainy seasons and the northeast monsoon in winter season. The average rainfall ranges from $1300-3200 \mathrm{~mm}$ and the annual average temperature ranges between $21^{\circ} \mathrm{C}$ in north and $27^{\circ} \mathrm{C}$ in south [4]. With the complexity in topography and climate diversity 6 categories of the forest types has been identified viz., natural forest, timber forest, bamboo forest, mangrove forest, rocky mountain forest and plantations. The country is divided into 7 ecological zones (Northern Mountains, Red river delta, Mekong delta, North central, South central, Eastern highlands and southeast) and plantation of Acacia, Eucalyptus, pine and rubber was done long back for commercial purposes, which has contributed significantly to forest cover [4].

\section{Collection of specimen}

The survey was conducted throughout the country and the specimens including leaves, flower or fruit of different Alpinia species were collected and were identified [5]. The voucher specimens collected from the field have been deposited with the Institute of Ecology and

*Corresponding author: Nguyen Phuong Hanh, Department of Plant Resources, Institute of Ecology and Biological Resources (IEBR), Vietnam Academy of Science and Technology (VAST), 18 Hoang Quoc Viet, Nghia Do, Cau Giay, Hanoi, Vietnam, Tel: 0904249861; E-mail: binhnq@vnmn.vast.vn

Received February 20, 2014; Accepted March 10, 2014; Published March 17, 2014

Citation: Hanh NP, Binh NQ, Adhikari BS (2014) Distribution of Alpinia (Zingiberaceae) and their use pattern in Vietnam . J Biodivers Endanger Species 2: 121. doi:10.4172/2332-2543.1000121

Copyright: (c) 2014 Anouti FA. This is an open-access article distributed under the terms of the Creative Commons Attribution License, which permits unrestricted use, distribution, and reproduction in any medium, provided the original author and source are credited. 
Citation: Hanh NP, Binh NQ, Adhikari BS (2014) Distribution of Alpinia (Zingiberaceae) and their use pattern in Vietnam . J Biodivers Endanger Species 2: 121. doi:10.4172/2332-2543.1000121

Page 2 of 5

\begin{tabular}{|c|c|c|c|c|c|c|}
\hline Name & Local name & Altitude (m) & Habitat & Nativity & Parts used & Use(s) \\
\hline $\begin{array}{l}\text { A. blepharocalyx } \mathrm{K} \text {. } \\
\text { Schum. }\end{array}$ & $\begin{array}{l}\text { Riềng dài lông } \\
\text { mép; Riềng bẹ }\end{array}$ & $100-1600$ & on wet slopes & China & $\begin{array}{l}\text { Rhizome, } \\
\text { fruit, seed }\end{array}$ & $\begin{array}{l}\text { Juice obtained from rhizomes, fruit and seed used to } \\
\text { treat for digestive disorders, abdominal ache due to } \\
\text { cold and stomachache by oral use }\end{array}$ \\
\hline $\begin{array}{l}\text { A. breviligulata (Gagnep.) } \\
\text { Gagnep. }\end{array}$ & Riềng lưỡi ngắn & $30-700$ & $\begin{array}{l}\text { along the streams in } \\
\text { secondary forest }\end{array}$ & $\begin{array}{l}\text { Ind. or.; } \\
\text { China }\end{array}$ & Rhizome & $\begin{array}{l}\text { Use for normal abdominal ache by drinking water } \\
\text { (by oral use) or topical on the abdomen }\end{array}$ \\
\hline $\begin{array}{l}\text { A. oblongifolia Hayata } \\
\text { (Retz). } \\
\text { Rosc - (A.chinensis) }\end{array}$ & $\begin{array}{l}\text { Lương khương; } \\
\text { Riềng tàu }\end{array}$ & $100-2500$ & $\begin{array}{l}\text { on road sides slopes } \\
\text { and under the canopy } \\
\text { of secondary forest }\end{array}$ & Formosa & Rhizome & $\begin{array}{l}\text { Juice extracted from boiled rhizomes used to } \\
\text { stimulate digestion (by oral use) and treat abdominal } \\
\text { ache due to cold, stomachache, cough, respiratory } \\
\text { inflammation, arthritis and caning (whipping), } \\
\text { rhizomes soaked in wine or vinegar to cure } \\
\text { ringworm and fresh crushed rhizomes poultice on } \\
\text { caning (whipping) }\end{array}$ \\
\hline A. conchigera Griff. & Riềng rừng & $200-1100$ & $\begin{array}{l}\text { under wet forest and } \\
\text { also cultivated in } \\
\text { garden }\end{array}$ & Ind. or & $\begin{array}{l}\text { Rhizome, } \\
\text { leaves }\end{array}$ & $\begin{array}{l}\text { Boiled juice from rhizome or leaves to treat diseases } \\
\text { such as indigestion, spleen, abdominal pain and } \\
\text { water from boiled leaves used for bath. Burned } \\
\text { leaves used for rheumatic pain. }\end{array}$ \\
\hline A. galanga (L.) Willd. & Riềng nếp & $100-1300$ & $\begin{array}{l}\text { Grow in shade and } \\
\text { also cultivated }\end{array}$ & As. trop & $\begin{array}{l}\text { Rhizome, } \\
\text { fruit, seed }\end{array}$ & $\begin{array}{l}\text { Dried rhizomes, fruits and seed used for treating } \\
\text { flatulence, abdominal ache, dysentery, diarrhea, } \\
\text { vomiting, cough, drunk, sore throat, by drink. } \\
\text { Rhizomes soaked in the salt used for anti-thirst } \\
\text { and help during tiresome work. Rhizome soaked } \\
\text { in alcohol to treat ringworm only experienced by } \\
\text { people in Thai Nguyen province only through topical } \\
\text { skin }\end{array}$ \\
\hline A. globosa (Lour.) Horan. & Sẹ, Mè tré & $100-300$ & under wet forest & China & $\begin{array}{l}\text { Rhizome and } \\
\text { fruits }\end{array}$ & $\begin{array}{l}\text { Juice obtained from boiled fruits used to treat } \\
\text { diseases such as stomachache, abdominal ache, } \\
\text { indigestion, cholera, dysentery, vomiting, excessive } \\
\text { urination at night and natural ejaculation (by oral } \\
\text { use), rhizomes and fruits used for anti-vomiting }\end{array}$ \\
\hline A. hainanensis K. Schum. & Riềng hải nam & $<1500$ & $\begin{array}{l}\text { under wet forest and } \\
\text { along stream course }\end{array}$ & China & Fruits & $\begin{array}{l}\text { Fruits used to treat abdominal ache and bloating } \\
\text { diseases by drinking juice obtained from boiled fruits }\end{array}$ \\
\hline A. latilabris Ridl & Ry & $<800$ & $\begin{array}{l}\text { often grows in damp } \\
\text { shady places with } \\
\text { open forest }\end{array}$ & Penins. Mal & Rhizome & $\begin{array}{l}\text { Juice obtained from boiled rhizomes to treat } \\
\text { gastrointestinal diseases }\end{array}$ \\
\hline $\begin{array}{l}\text { A. malaccensis (Burm. f.) } \\
\text { Rosc. }\end{array}$ & Riềng malacca & $<1200$ & $\begin{array}{l}\text { along streams and } \\
\text { under the forest } \\
\text { canopy with high } \\
\text { concentration in wet } \\
\text { places }\end{array}$ & Penins. Mal & Rhizome & $\begin{array}{l}\text { Juice obtained from boiled rhizomes to treat } \\
\text { intestinal diseases and crushed rhizomes used to } \\
\text { treat scabies (only topical skin) }\end{array}$ \\
\hline A. mutica Roxb. & Riềng không mũi & $100-1000$ & $\begin{array}{l}\text { grow in wet places } \\
\text { under the forest and } \\
\text { along streams }\end{array}$ & Ind. or & Rhizomes & $\begin{array}{l}\text { Crushed rhizomes mixed with water used to treat } \\
\text { stomachache and abdominalache and help in } \\
\text { digestion }\end{array}$ \\
\hline A. oxymitra K. Schum. & Riềng núi & $<300$ & $\begin{array}{l}\text { grow in wet places } \\
\text { under the forest and } \\
\text { along streams }\end{array}$ & Siam & Flower & Flower soaked in wine to treat arthritis \\
\hline A. officinarum Hance & Riềng & $<1500$ & $\begin{array}{l}\text { grow under forest } \\
\text { canopy and also in } \\
\quad \text { garden }\end{array}$ & China & Rhizome & $\begin{array}{l}\text { Juice obtained from boiled rhizomes to stimulate } \\
\text { digestion, treat stomachache and malaria and } \\
\text { crushed rhizomes soak in wine/vinegar or using } \\
\text { fresh herb to cure ringworm by topical skin }\end{array}$ \\
\hline A. oxyphylla Miq. & Ích trí & $<1400$ & $\begin{array}{c}\text { grow under shade with } \\
\text { dense canopy }\end{array}$ & China & Fruit & $\begin{array}{l}\text { Juice obtained from boiled dried fruits used for } \\
\text { abdominalache, stomachache, diarrhea, vomiting, } \\
\text { bed wetting, dysentery, excessive urination at night } \\
\text { and natural ejaculation }\end{array}$ \\
\hline $\begin{array}{l}\text { A. pinnanensis Wu Te-lin } \\
\text { \& S. J. Chen }\end{array}$ & Riềng pinna & $500-1200$ & $\begin{array}{l}\text { grow along srteams, } \\
\text { wet slopes and under } \\
\text { forest canopy }\end{array}$ & China & $\begin{array}{c}\text { Rhizome and } \\
\text { tubers }\end{array}$ & $\begin{array}{l}\text { Treating cough, fever, abdominal ache, cures } \\
\text { flatulence and stomachache (by oral use) }\end{array}$ \\
\hline A. tonkinensis Gagnep & Riềng Bắc Bộ & $100-1200$ & $\begin{array}{l}\text { grows under } \\
\text { secondary forest }\end{array}$ & Tonkin & $\begin{array}{l}\text { Rhizome, } \\
\text { fruit and } \\
\text { seed }\end{array}$ & $\begin{array}{l}\text { Juice obtained from boiled rhizomes, fruit and seed } \\
\text { used for stomachache, indigestion and arthritis (by } \\
\text { oral use) }\end{array}$ \\
\hline $\begin{array}{l}\text { A. zerumbet (Pers.) Burtt } \\
\text { \& R. M. Smith. }\end{array}$ & $\begin{array}{l}\text { Riềng đẹp, } \\
\text { Riềng ấm }\end{array}$ & $100-1500$ & $\begin{array}{l}\text { grow along srteams, } \\
\text { wet slopes and also } \\
\text { cultivated land }\end{array}$ & $\begin{array}{l}\text { Costus } \\
\text { zerumbet }\end{array}$ & $\begin{array}{l}\text { Rhizome, } \\
\text { leaf, flower, } \\
\text { and seed }\end{array}$ & $\begin{array}{l}\text { Juice obtained from boiled leaves, flower, rhizomes } \\
\text { and seeds used to treat fever, stomachache, } \\
\text { abdominalache, bloating, indigestion and diarrhea } \\
\text { Ind. or - Indian oriental region, As Trop - Asia } \\
\text { tropical region and Penins. Mal - Peninsular } \\
\text { Malaysian region }\end{array}$ \\
\hline
\end{tabular}

Table 1: Ethno-ecology of different species of Alpinia in Vietnam.

Biological Resources at Vietnam Academy of Science and Technology (VAST) and Vietnam National Museum of Nature (VNMN).

\section{Ethno-botanical survey}

During the survey the information on the ethno-botanical use 

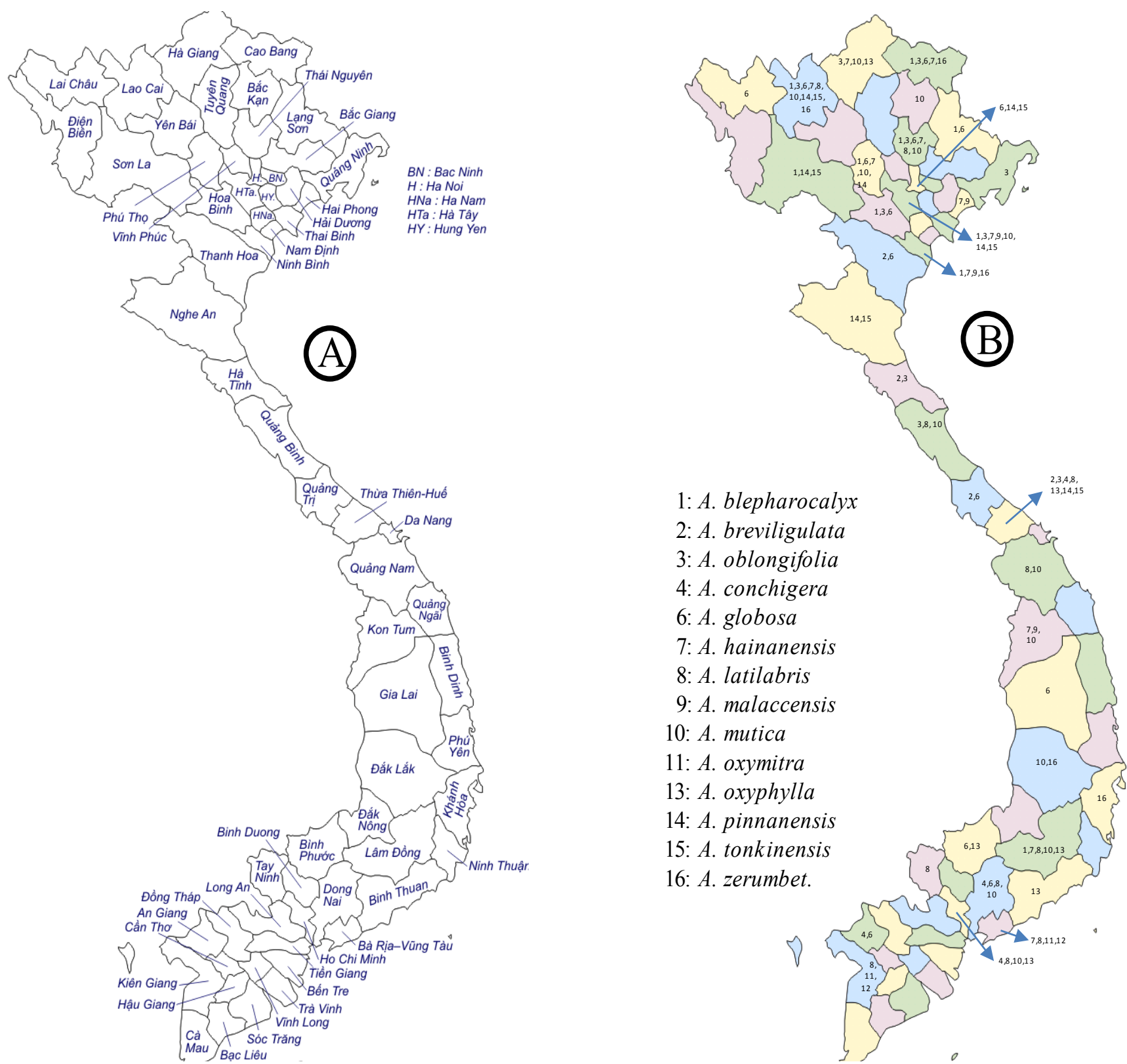

Figure 1: Map of Vietnam (A) and distribution of sixteen Alpinia species in various provinces of Vietnam (B). 1. A. blepharocalyx; 2. A. breviligulata; 3. A oblongifolia; 4. A. conchigera; 6. A. globosa; 7. A. hainanensis; 8. A. latilabris; 9. A. malaccensis; 10. A. mutica; 11. A. oxymitra; 13. A. oxyphylla; 14. A. pinnanensis; 15. A. tonkinensis and 16. A. zerumbet.

of different species of Alpinia in various provinces was conducted during 2010-2012. The information gathered through interviews of local people, traditional healers, collectors and traders independently considering their age groups and sex (mainly women as they use and keep indigenous knowledge), and also group discussions with the help of semi-structured questionnaire and the guided field walk in each province as described [6]. The information on ethno-botanical use, such as medicinal, parts' used and the modes of medicine preparation along with the availability of the plants in the area and the local name were documented and identified [7]. The data was analyzed in Excel spreadsheet.

\section{Results and Discussion}

The genus Alpinia (in memory of an Italian botanist; Prospero Alpina, 1533-1617) is the largest, most widespread and taxonomically complex genus under family Zingiberaceae with 230 species occurring throughout the tropical and subtropical Asia (Sri Lanka and the Western Ghats of India to China, Japan, all of southeast Asia, the Pacific as far as Fiji, Samoa, and the Caroline Islands, and Australia as far south as northern New South Wales) [8,9]. Alpinia species usually prefers to grow in humid places, like weather from cold to warm, hence their distribution is widespread in Vietnam.

\section{Habitat preference and distribution}

In all 31 species of Alpinia has been recorded from Vietnam shows 
Citation: Hanh NP, Binh NQ, Adhikari BS (2014) Distribution of Alpinia (Zingiberaceae) and their use pattern in Vietnam . J Biodivers Endanger Species 2: 121. doi:10.4172/2332-2543.1000121

Page 4 of 5

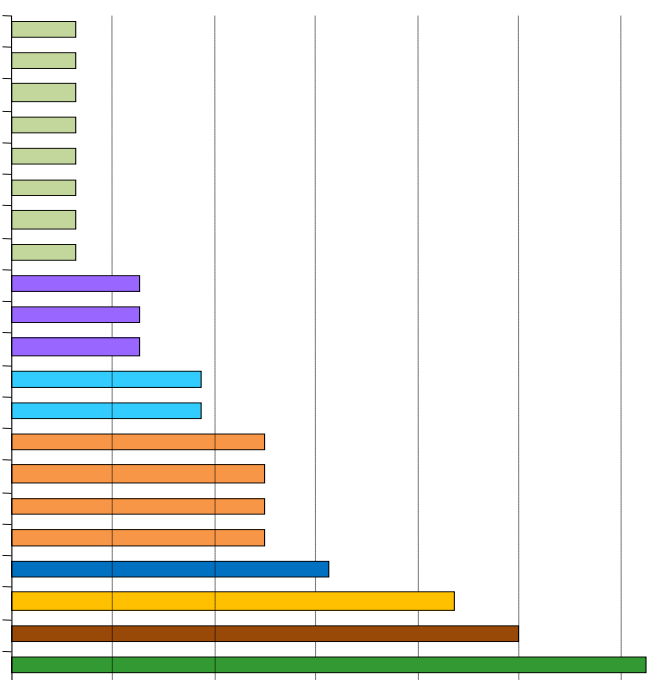

Figure 2: Percent use of different Alpinia species for various ailments. high richness of Alpinia species as compared to the neighboring country Thailand (17 species with 2 varieties) [10]. Out of these 31 species, 16 are being used for medicinal purposes by the local people. The details including latin name, local name, altitude, habitat, parts used, mode of preparation and medicinal uses of each species is given in Table 1. Most of the species of Alpinia prefers to grow in wet and shady places such as under forest canopy, while others like to grow along the road sides or grassy slopes, viz. Alpinia hainanensis and Alpinia oblongifolia (A. chinensis) at varying altitude from 30 to $1500 \mathrm{~m}$. The distribution of each Alpinia species (Figure 1) which indicates that the majority of Alpinia species distributed in the northern provinces of the country. Much of Alpinia species are native to China followed by species from Indian origin.

\section{Flowering and fruiting}

Among important phenophases, flowering and fruiting of Alpinia species mainly depends on their habitat preferences (Figure 2). Among all 16 medicinally used Alpinia species, the species follow the pattern of growth period: initiation of growth period (25\%, A. oxymitra, A. globosa, A. oblongifolia and A. oxyphylla), mid-growth period (56\%, A. blepharocalyx, A. hainanensis, A. malaccensis, A. officinarum, A.

A. oxymitra

A. globosa

A. oblongifolia

A. oxyphylla

A. blepharocalyx

A. hainanensis

A. malaccensis

A. officinarum

A. zerumbet

A. conchigera

A. galanga

A. pinnanensis

A. tonkinensis

A. latilabris

A. breviligulata

A. mutica
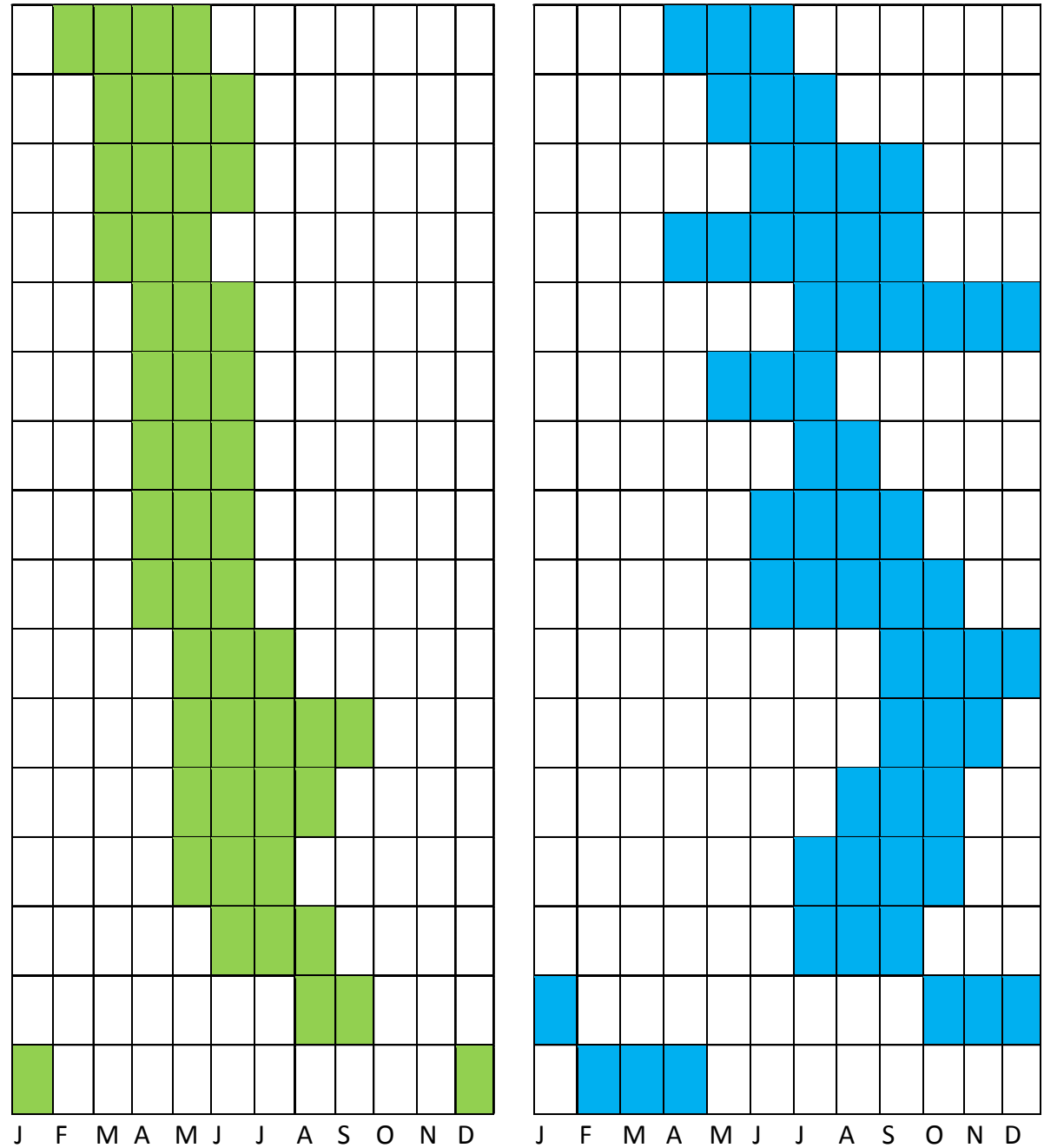

Figure 3: Flowering and fruiting in various Alpinia species used for medicinal purposes in Vietnam. 
zerumbet, A. conchigera, A. galanga, A. pinnanensis, A. tonkinensis) and later growth period (13\%, A. latilabris, A. breviligulata), while lone species $A$. mutica flowers quite late (December-January). Most of the species (69\%) bear fruits for a period between 3 to 4 months mostly in June to October, while species like A. oxyphylla, A. blepharocalyx and A. zerumbet takes more than 5 months.

\section{Use pattern}

Among plant parts, the use pattern of various parts is as follows: rhizome $(48 \%)>$ fruit $(22 \%)>$ seed $(15 \%)>$ leaves and flower (7\% each). The different parts of these 16 medicinal plant species of Alpinia are used in 27 different diseases. Among diseases gastrointestinal disease (digestive disorders, indigestion, stimulate digestion, dysentery, abdominal pain, bloating, flatulence, stomachache and diarrhea), cholera, rheumatism, arthritis, respiratory inflammation (cough, sore throat and bronchitis) and fever are being treated (Figure 3).

\section{Conclusion}

In total 31 Alpinia species have been reported from Vietnam, of which 16 species are traditionally used for health care by Vietnamese. Most of the species used to treat common diseases, which are very effective in stomachache, indigestion, cholera, dysentery, diarrhea, vomiting, excessive urination at night and natural ejaculation from different plant parts (rhizome, tuber, leaves, flowers, seed and fruit) and among them rhizome is mostly used. Most of the medicinal preparations (decoction or extract) are administered orally. Until now, there are many species used to treat incurable diseases such as fatty liver, cirrhosis of liver and cancer, which are usually harvested from the wild. The traditional healers and the elderly people have familiarity with the plant species along with its uses. Whereas, the younger generation does not know most of the plants and their medicinal uses, due to which the folk is under threat and squeezing rapidly. Therefore, there is a need to identify young people who may take this folk ahead in the supervision of elders or traditional healers. The present distribution of Alpinia also suggests that the species specific sites may be identified for the conservation in nearby provinces in their natural habitats similar to Gardens at different places in the country (Sa Pa, Tam Dao and Van Dien Medicinal Herb Stations, Ha Noi University of Pharmacy's and Military Medical Institute's Gardens, Garden of medicinal plants in Ba Vi Mountain and Centre of Plants for Breeding in Da Lat).

\section{References}

1. Calixto JB (2005) Twenty five years of research on medicinal plants in Latin America : a personal review. J Ethnopharmacol 100:131-134.

2. Anonymous (2008) $4^{\text {th }}$ Country report. Vietnam's Implementation of the biodiversity convention, Ministry of Natural resources and environment, Vietnam Environment Administration.

3. Van NDN, Tap N (2008) An overview of the use of plants and animals in traditional medicine systems in Vietnam. Traffic Southeast Asia, Greater Mekong Programme, Ha Noi, Vietnam.

4. Jong W, Sam DD, Hung TV (2006) Forest rehabilitation in Vietnam: histories, realities and future. Indonesia: Centre for International Forestry Research (CIFOR).

5. Ho P (2000) Zingiberaceae. An illustrated flora of Vietnam. Publication House of Younger 3: 432-461.

6. Martin GJ (1995) Ethnobotany: A methods manual. Chapman and Hall, London

7. Vo VV (1996) Dictionary of Vietnamese Medicinal Plants. Medicine Publisher, Ho Chi Minh City.

8. Larsen K, Lock JM, Maas H, Maas PJM (1998) Zingiberaceae. In: Kubitzk $\mathrm{K}(\mathrm{Ed})$. The families and genera of vascular plants. Springer-Verlag, Berlin, Germany, 4: 474-495.

9. Smith RM (1990) Alpinia (Zingiberaceae): a proposed new infrageneric classification. Edinburgh Journal of Botany 47: 1-75.

10. Saaensouk S, Chantaranothai P, Larsen K (2003) Notes on the genus Alpinia (Zingiberaceae) in Thailand. Thai Forest Bulletin 31: 95-104. 